\title{
Pohjoismaisen työelämän mallin nousu ja (t)uho
}

Hvid, Helge \& Falkum, Eivind (toim.), Work and Wellbeing in the Nordic Countries. Critical Perspectives on the World's Best Working Lives. Lontoo, Routledge, 2019, 377 sivua.

Pohjoismaisen työelämän mallin erinomaisuus, sitä uhkaava globalisaatio sekä työelämän muutos ovat työelämän tutkimuksen kestoaiheita. Work and wellbeing in the Nordic countries on teos, joka jälleen tarttuu tähän asetelmaan ja kokoaa 27:n norjalaisen ja tanskalaisen tutkijan työtä yksiin kansiin. Pohjoismaissa on maailman paras työelämä ja kirjan esitellään kertovan, mikä tuottaa ja ylläpitää hyvää työelämää. Lukijana kuitenkin koen, että kirjan sisältö vastaa enemmän alaotsikkoaan, tarjoten "kriittisiä näkökulmia maailman parhaaseen työelämään". Tällöin jatkokysymys olisikin: Pohjoismaista työelämää on pidetty maailman parhaana, mutta mitä siitä kertoo tuorein tutkimus? Esittelystä olisi tullut koukuttavampi, jos se olisi vahvemmin esitetty tämän jännitteen ja lukujen tarjoaman uuden tiedon kautta. Tämä on yksi monista kokoelman toimittamiseen liittyvistä heikkouksista, jotka antavat teoksesta huolimattoman vaikutelman.

Kirjan sisältö on jaettu viiden erilaisen teeman alle, jotka ovat vapaasti käännettynä: (I) Pohjoismaisen mallin historia ja perusteet, (II) Organisaatiot ja johtaminen Pohjoismaissa, (III) Oppiminen, osallisuus ja yhdenvertaisuus työelämässä, (IV) Uusi julkisjohtaminen Pohjoismaissa sekä (V) Työn tekemisen muuttuvat ehdot ja prekarisaatio. Kirjan paras anti on ajankohtaisissa ja kiinnostavissa kansainvälisiä johtamisoppeja koskevissa luvuissa, joita esittelen seuraavaksi lyhyesti ja valikoiden.
Yhtenä pohjoismaisen työelämämallin keskeisimpinä piirteinä on pidetty työntekijöiden laajoja vaikutusmahdollisuuksia työtään koskeviin päätöksiin sekä päätöksentekoon organisaatiossa. Luvussa Workplace democracy under pressure norjalaiset tutkijat Eivind Falkum, Ida Drange, Heidi Enehaug ja Bitten Nordrik osoittavat kuitenkin vaikutusmahdollisuuksien olevan vähenemässä. Erityisen huomionarvoista on ristiriita rakenteiden ja kokemusten välillä. Tutkijoiden ja ammattiliittojen yhteistyössä tekemissä työntekijäkyselyissä ei havaittu muutoksia työpaikkojen formaaleissa työntekijäedustuksen rakenteissa vuosina 2009-2017. Pohjoismaisen mallin mukaisesti luottamusmiehet edustavat edelleen liittoja työpaikoilla, palkkaneuvotteluja käydään, työturvallisuutta ja työympäristön laatua valvotaan työryhmissä ja työntekijöiden valitsemalla edustajalla on pääsy johtokuntaan. Kuitenkin lähes puolet kyselyyn vastanneista työntekijöistä koki päätöksenteon työelämässä muuttuneen autoritaarisemmaksi. Vahvimmin näin arvioivat ulkomaalaisessa omistuksessa olevien yritysten työntekijät, mutta näin vastattiin myös valtio-omisteisissa yhtiöissä sekä julkisella sektorilla.

Kyselyjen lisäksi tutkijat tarkastelivat työpaikkademokratian haasteita suurta monikansallista yhtiötä koskevan tapaustutkimuksen avulla. Kohteena olevan yrityksen hallinto päätti ottaa käyttöön samat toiminnanohjausja hallintojärjestelmät sen kaikissa eri puolilla maailmaa sijaitsevissa toimipisteissä. Yrityksen tavoitteena oli yhdenmukaistaa prosesseja sekä suunnitella ja toimeenpanna uusi yksilöiden suoriutumisen mittaamiseen paremmin soveltuva johtamisjärjestelmä. Sekä ammattiliitot että luottamusmiehet raportoivat, 
ettei työntekijöiden myötämäärämisoikeutta kunnioitettu, eikä heidän näkemyksiään otettu huomioon suunnittelu- tai toimeenpanovaiheessa. Keskeiset päätökset tehtiin siis muualla. Keskeinen pohjoismaista työpaikkademokratiaa uhkaava johtopäätös onkin, että yhtiön hallinto voi väistää formaalit työntekijäedustuksen rakenteet päätöksenteossaan.

Hieman optimistisemman kuvan pohjoismaisen mallin ja työntekijäjärjestöjen vaikutusmahdollisuuksista antavat tutkijat Peter Hagedorn-Rasmussen ja Pål Klethagen luvussaan, jossa he arvioivat miten kansainväliset johtamisopit, kuten lean-tuotantomalli, ovat vaikuttaneet työelämään Tanskassa ja Norjassa. Johtamisopit, kuten lean, esitetään usein universaalina tietona, joka matkustaa maasta toiseen ja sovellettaessa muuttaa organisaatioita sekä työtä mallin oppien mukaan. Organisaatiot eivät kuitenkaan muutu näin ideaalityyppisesti. Sen sijaan johtamisoppi muotoutuu ja muuttuu aktiivisessa vuorovaikutuksessa instituutioiden sekä paikallisten olosuhteiden kanssa. Erityisesti tutkijat nostavat esiin sen, miten lean-tuotantomalli on levinnyt Pohjoismaihin siitä huolimatta, että sen on arvioitu haastavan pohjoismaisen autonomisen työn organisoinnin perinteet. Kustannustehokkuutta korostavan lean-ajattelun kritiikittömän soveltamisen sijaan ammattiliitot ja tutkijat ovat pyrkineet Pohjoismaissa myötävaikuttamaan siihen, miten lean-johtamisoppia sovelletaan, muodostaen pohjoismaisen version lean-johtamisesta. Tutkimuksellinen työelämän kehittämisohjelmien perinne on ollut merkittävä väylä, jonka kautta lean on levinnyt pohjoismaihin. Tutkijat eivät kuitenkaan anna yksiselitteistä vastausta siihen, ovatko ammattiliitot, tutkijat ja työelämän kehittämisohjelmat onnistuneet torjumaan leaniin liitetyt uhkakuvat työn intensivoitumisesta ja työntekijöiden autonomian rapautumisesta.

Uusi julkisjohtaminen on ansainnut teoksessa oman osionsa, jonka alla työn muutosta tarkastellaan. Koska sosiaali- ja terveysalan sekä hoivatyön ongelmat ovat olleet laajemmin julkisessa keskustelussa, esittelen tässä, mitä Christin Thea Wathne kertoo luvussaan poliisiprofession ja -työn muutoksesta Norjassa. Poliisin keskeisimmät tehtävät ovat historiallisesti muuttuneet sen mukaan, millaiseksi julkisten instituutioiden yhteiskunnallinen rooli on ymmärretty. Keskeisimmän jännitteen luo toisen maailmansodan jälkeen korostunut poliisin rooli yhtäältä (aseellisen) voiman käyttäjänä, toisaalta yleisen turvallisuuden takaajana sekä rikollisuuden ennaltaehkäisijänä. Jälkimmäinen humanistinen näkemys vahvistui 1960- ja 70-luvuilla kun julkista hallintoa hajautettiin. Paikallisuuden ja polisiin autonomian myötä korostuivat myös poliisin avunantotehtävät sekä yhteistyö kansalaisten kanssa. Wathne kuitenkin esittää, että uusi julkisjohtaminen on keskittänyt ja uudelleenbyrokratisoinut hallintoa. Tulosjohtamisen ja mitattavuuden periaatteet ovat muuttaneet poliisin ydintehtävää militaristisemmaksi. Tällöin korostuvat niin sanotut kovat tehtävät, kuten vakavan rikollisuuden ja terrorismin torjunta. Yhteistyötä ja ennaltaehkäiseviä tehtäviä sekä niiden onnistumista on puolestaan vaikea mitata. Markkinaperiaatteiden mukaisesti poliisin pehmeitä tehtäviä on ulkoistettu ja siirretty yksityisten turvallisuus- ja vartiointiliikkeiden tehtäväksi, mikä kapeuttaa poliisityön sisältöä. Samalla poliisin julkisuuskuva on muutoksessa. Wanthen mukaan uuden julkisjohtamisen mukainen keskittäminen on paitsi standardoinut ja yksipuolistanut poliisiprofession sisältöjä, myös vähentänyt ammatillista autonomiaa ja etäännyttänyt poliisia kansalaisista.

Kirjan päättävässä luvussa toimittajat spekuloivat yleisellä tasolla sitä, onko pohjoismaisen mallin erityispiirteitä olemassa enää sadan vuoden kuluttua. Yhtäältä kysymykseen vastataan uhoamalla, että erinomainen pohjoismainen malli voi levitä ympäri maailman. Toisaalta keskustelut ammattiliittojen laskevista jäsenmääristä, ammattiliitoista kestävän kehityksen esteinä ja (palkka)työn lopusta esitetään kehityskulkuina, jotka voivat johtaa mallin tuhoon. Nämä keskustelut vaikuttavat 
kuitenkin lopetuksena irrallisilta. Kirja olisi kaivannut tuloksia yhteenvetävän päätösluvun: mitä tämä kokoelma kertoo pohjoismaisen työelämän tilasta, haasteista ja tulevaisuudesta?

Suurin kritiikki kohdistuukin toimitustyöhön, joka jättää kirjan otsikosta lähtien paljon toivomisen varaa. Kirjan esittelyteksti ja johdanto eivät esittele selkeästi kirjan keskeistä punaista lankaa. Johdanto ei myöskään perinteisen tiedekirjoittamisen konventioiden mukaisesti perustele, miksi tämä teos on tarpeellinen juuri nyt, ja miten teos sijoittuu suhteessa olemassa olevaan kirjallisuuteen. Nämä jäävät pitkälti yleisön ja lukijoiden arvioitavaksi. Kirjan ensimmäisellä lehdellä esitellään myös kirjan toimittajat, mutta kirjasta puuttuu osio, jossa esiteltäisiin kaikki kirjoittajat. Ketä siis kirjan kirjoittajat ovat ja miksi juuri he ovat osallistuneet kirjan tekemiseen? Kirja myös pyrkii kertomaan pohjoismaisen työelämän erityisyydestä, mutta yksikään luvuista ei käytä vertailevan tutkimuksen teorioita tai menetelmiä. Kaikkia lukuja ei myöskään ole ohjattu osallistumaan keskusteluun Pohjoismaisesta työelämän mallista. Kertooko toimitustyön puutteellisuus sitten omaa tarinaansa akateemisen työn hektisyydestä ja vaikeuksista syventyä kirjoitusprojektiin, vai kustannusalan muutoksesta, jonka myötä kustantajat tekevät yhä vähemmän toimitustyötä? Sekin jää lukijan arvion varaan. Lisäksi esittelyssä mainitaan, että kirja käsittelee työoloja Norjassa, Ruotsissa, Tanskassa ja Suomessa. Johdannosta lukija saa kuitenkin selville, että kirjan esittelemä tutkimus keskittyy Norjaan ja Tanskaan. Suomalaista työelämän tutkijaa toki aina mietityttää, miksei Suomi ole mukana tämänkaltaisissa kokoelmateoksissa. Eikö Suomea todella mielletä pohjoismaisen mallin ytimeen vai onko syy pragmaattisempi - olemmeko me suomalaiset tutkijat heikosti pohjoismaisten tutkijoiden kanssa verkostoituneita?

Kirja onkin ensisijaisesti tavanomainen käsikirja, johdanto pohjoismaisen työelämäsuhteiden mallin perusteisiin ja työelämän muutoksien empiiriseen tutkimukseen. Teemat ovat pääosin perinteisiä kuten myös yksittäisissä luvuissa esitellyissä tutkimuksissa käytetyt teoriat ja menetelmät (kuten tapaustutkimukset ja työntekijäkyselyt). Osa luvuista perustuu empiiristen tulosten esittelyyn, osa puolestaan muistuttaa enemmän kirjallisuuskatsausta koostaen sen, mitä tietystä aiheesta tiedetään tällä hetkellä. Kokoelma ei sisällä myöskään näkökulmia maahanmuuttoon tai sukupuolten tasa-arvoon työelämässä. Kirjan keskeisimpänä vahvuutena ja kontribuutiona voi nostaa esiin sen, miten kirjoittajat kääntävät aiemmin pohjoismaisilla kielillä julkaistujen tutkimusten tuloksia englanniksi laajemman yleisön saataville. Siten kirjaa voi suositella perinteisestä pohjoismaisen työelämän tutkimuksesta kiinnostuneille tutkijoille, opettajille ja työelämän muutoksia koskevia keskusteluja seuraaville.

\section{Kirjoittaja}

Armi Mustosmäki, YTT, tutkijatohtori, Tampereen yliopisto, sähköposti: armi.mustosmaki@tuni.fi 